\title{
The Role of Gestures in the Construction of Multimodal Metaphors: Analysis of a Political-Electoral Debate
}

\section{o papel dos gestos na construção de metáforas multimodais: análise de um debate político-eleitoral}

\author{
Maíra Avelar Miranda* \\ Universidade Estadual do Sudoeste da Bahia \\ Vitória da Conquista - Bahia / Brasil \\ Paulo Henrique Aguiar Mendes** \\ Universidade Federal de Ouro Preto \\ Ouro Preto - Minas Gerais /Brasil
}

\begin{abstract}
This paper intends to analyze the role of gestures in the construction of multimodal metaphors in the "political-electoral debate" genre. Theoretically, we considered that metaphoric gestures can be analyzed as expressions of conceptual metaphors. We mainly approached and illustrated the importance of spatial orientation in the emergence of the metaphors in the political discourse. Methodologically, we have selected four sequences of a second-tour debate. Starting from the operational concept of gesture excursion, we specifically observed the multimodal metaphoricity in speech and gesture compounds. After analyzing the metaphors found in the debate sequences, we established a continuum between metaphors of a conventional nature and those of a new nature. We also tried to establish a comparative relation between the metaphors used by the two candidates, Dilma Rousseff (from the Labor Party) and José Serra (from the Social Democratic Party).
\end{abstract}

KEYWORDS: Multimodal metaphors; Metaphoric gestures; Political-electoral Debates.

\footnotetext{
*mairavelar@uesb.edu.br

** pauloham@yahoo.com.br
} 


\begin{abstract}
RESUMO: Este artigo pretende analisar o papel dos gestos na construção de metáforas multimodais no gênero "debate político-eleitoral". Do ponto de vista teórico, levamos em consideração que os gestos metafóricos podem ser analisados como expressões de metáforas conceptuais. Abordamos e ilustramos, sobretudo, a importância da orientação especial na emergência de metáforas no discurso político. Do ponto de vista metodológico, selecionamos quatro sequências de um debate de segundo turno. Partindo do princípio operacional de excursão gestual, observamos, especificamente, a metaforicidade multimodal em compostos verbo-gestuais. Após analisar as metáforas encontradas nas cenas de debate, estabelecemos um continuum entre metáforas que possuem uma natureza convencional e aquelas que possuem uma natureza nova. Além disso, tentamos estabelecer uma relação comparativa entre as metáforas utilizadas pelos dois candidatos: Dilma Rousseff (do PT) e José Serra (do PSDB).
\end{abstract}

PALAVRAS-CHAVE: Metáforas multimodais. Gestos metafóricos. Debates politico-eleitorais.

\title{
Introduction
}

In this paper, we aim to analyze the emergence of multimodal metaphors in online face-to-face interactions that belong to the discursive genre of the "political-electoral debate", taking into consideration two variables: the verbal, belonging to the auditory modality, and the gestural, belonging to the visual modality. Starting from the Conceptual Metaphor Theory (LAKOFF \& JOHNSON, 1980), in which an abstract target domain is understood in terms of a concrete source domain, we intend to analyze the metaphors that gradually emerge in the interaction between the candidates. We assume the hypothesis that the more entrenched in our conceptual system the metaphoric expression is, the more difficult it is to recognize it as a metaphoric expression. On the other hand, the less entrenched in our conceptual system the metaphoric expression is, the easier it is to recognize it as a metaphoric expression.

In order to demonstrate the inter-relations between these two modalities, we have selected scenes from two second-round debates of the Brazilian presidential elections, broadcasted by two different TV channels: one broadcasted by Bandeirantes, which will be used as an illustrative corpus, and another broadcasted by Record, which will be used as our analysis corpus. We intend to perform a comparative analysis of the emergence of multimodal metaphors in the discourse of the candidates that participated in the debates, specifically observing the multimodal metaphoricity in 
speech and gesture compounds (MÜLLER \& CIENKI, 2009), as well as the concept of gesture excursion (KENDON, 2004).

To perform these analyses, we selected four sequences from the Record debate that have the prototypical "question-answer-replyrejoinder" structure, in which we could recognize eleven spatial orientation metaphors in verbal-gestural compounds. Firstly, we have identified these metaphors and photographed their gesture strokes. After that, to properly address the online metaphors dynamicity and graduality, we categorized them in a continuum that ranges from more conventionalized to less conventionalized metaphors. The results confirmed our initial hypotheses that the more conventional the metaphors are, the more difficult it is to recognize the metaphoric nature of the expressions. On the other hand, the less conventional the metaphors are, the easier it is to recognize the metaphoric nature of the expressions, and, consequently, more gestural resources are used for directing the attention of the listener to what is being said or depicted by the gestures. After performing all the analyses, we demonstrated how the verbal and gestural features can interact in order to generate multimodal metaphors that can be more or less conventional, depending on the contextual environment of their emergence.

\section{Theoretical background}

\subsection{Metaphor and gestures}

We assume that metaphoric gestures can be analyzed as expressions of conceptual metaphors (CIENKI, 2008). Therefore, the study of gestures sustains a vision of the metaphor as a broadly cognitive phenomenon, as proposed by Lakoff \& Johnson (1980), and the notion that thought, even when referring to the most abstract subjects, is anchored in the embodied experience:

Gesture provides evidence for the embodied basis of thought. Gesture can provide an important locus for cognitive linguistic research on metaphor because it physically manifests the tenet that (many) metaphors are grounded in embodied action. Gestures can depict in space elements from the source domain of a metaphor, something which is not possible for metaphoric expressions in spoken languages (CIENKI, 2008, p. 16). 
As shown by Cienki, some metaphors can be conveyed through gestures without being conveyed in speech. Moreover, gestures can specifically describe elements from the source domain of a metaphor, which is not possible for metaphoric expressions from the spoken language. Therefore, the metaphors are not always unfolded by the verbal content of the utterance: "Gestures appear as an articulatory independent mode of expression which is used flexibly, and not only to illustrate the semantic content expressed verbally, nor only to treat abstract discourse objects metaphorically" (CIENKI \& MÜLLER, 2008, p. 493). Thus, they defend the argument that gestures are broadly recognized, not only as "illustrators", as was established by Sonesson (2001), but as intrinsic parts of the utterance.

In fact, there are important communicative reasons to why people gesticulate in a specific way when they talk: "These gestures embody ('give a body to') abstract, metaphorical ideas, and sometimes precede the language spoken to enhance the listener's understandings of the speaker's complex, abstract communicative intentions" (GIBBS, 2006, p. 450). Therefore, according to Gibbs (2006), we can, for instance, make a grasping movement in the air and thus say "I finally got the idea." The gesture, performed before the speech, in the case of this hypothetical example, can facilitate the understanding, by the receivers, of the metaphoric idea 'to understand' ('to get') an idea.

However, the relation between spoken language and gestures reveals that the metaphors can be instantiated in several modalities, without necessarily conveying the same conceptual metaphor: "Imagistic, embodied, and propositional modes of thinking interact during speaking (witness McNeill's concept of the growth point) and gestures may trigger new verbal metaphoric expressions" (CIENKI \& MÜLLER, 2008, p. 498). Therefore, there are cases in which there is a coincidence between gesture and speech, and others in which this coincidence does not occur.

In the following example, taken from our illustrative corpus, candidate Dilma Rousseff accuses her opponent, José Serra, by using a metaphor related to lying: "LYING IS HAVING A THOUSAND FACES". Afterwards, although not having used any verbal metaphoric expression, the candidate performs a downward vertical gesture that characterizes the TRUTH as a STRAIGHT LINE. This example demonstrates that the words and gestures can express different functions at the same time: the word "truthful" clarifies the target domain of the metaphor (TRUTH), while the gesture shows a way to metaphorically 
see that target, through the source domain representation (a STRAIGHT LINE). There is, thus, a coordination relation between gestures and speech, in which the gestures specifically represent the source domain, and the speech makes the target domain explicit. The example can be seen here below:

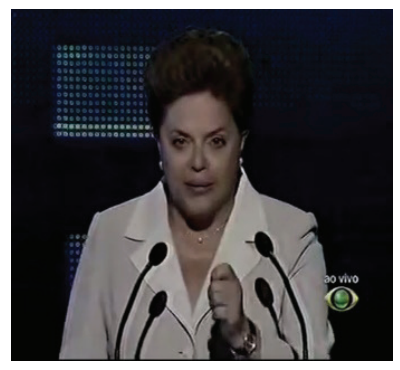

Então, eu acredito que a gente num pode ter duas caras. A gente tem de agir de maneira honesta.

So, I believe that we cannot have a thousand faces. We have to act in a truthful way.

Straight downward movement, with the left forearm, closed fist.

Figure 1: Gesture and speech that convey a metaphor "TRUTH IS STRAIGHT"

\section{Source: Bandeirantes debate}

On the other hand, there are cases in which the metaphorical expressions conveyed in the speech are not expressed through gestures: we can speak without gesticulating, for instance. There are also cases in which the gestures represent a low level of metaphoricity (concept that will be presented in greater detail below), as in the case of rhythmic gestures that serve only to emphasize the speech, without expressing a metaphoric shape with the body parts. There are also extreme cases in which two conceptual metaphors, involving the same target domain but showing distinct source domains, are expressed in the speech and gestures that co-occur with it.

An example of the latter, shown below, was also found in our illustrative corpus: when denouncing contradictions in his opponent's behavior, candidate José Serra performs body movements, as if he were promoting spatial division. Serra conveys in his speech the metaphor "LYING IS HAVING TWO FACES", which denunciates an opposition in Dilma's moral behavior. However, in the gestures, we have the performance of a spatial metaphor, in which the body positioning on opposite sides shows the contradiction mentioned in his speech. 


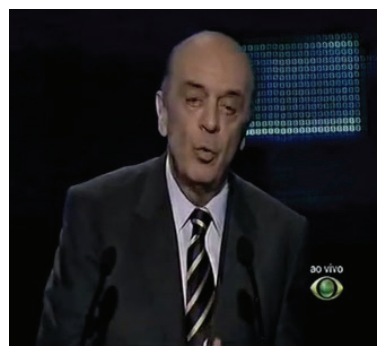

Aí se trata de ser coerente, de num ter duas caras,

Uma hora uma [cara],

So, it is about being coherent, of not having two faces, one moment one [face],

The body bends to the left side, with the face positioned on the same side.

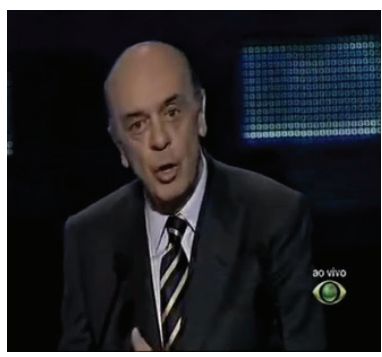

Outra hora, outra [cara].

Another moment, another [face].

The body bends to the right side, with the face positioned on the same side.

Figure 2: Gesture sequence indicating a spatial division

Source: Bandeirantes debate

Such an example demonstrates that there are metaphors expressed through words that cannot be expressed through gestures, especially in cases in which the source domain of the verbal metaphor cannot be expressed iconically in terms of shape, position, and movement. Hence, a contrast between the specificities (and limitations) of the visual modality appears, in which the metaphors have, above all, a special nature, and the specificities (and limitations) of the verbal modality, in which the metaphors have a symbolic nature, which can be expressed through references to abstract concepts, such as lies.

From the example of previously presented analyses, it is possible to assert that the gestural data do not only replicate the conceptual metaphors given by the verbal data. They instead provide additional clues to multimodal mappings, which can even be the gesture source (CIENKI, 2008). Therefore, the analysis of these data allows one to overcome the criticism made to the circularity of the Conceptual Metaphor Theory, which tautologically claims that "Verbal metaphoric expressions are evidence of conceptual metaphors (...). We know that because we see conceptual metaphors expressed in language" (CIENKI apud CIENKI, 2008, p. 16). 


\subsection{Gestures in multimodal metaphors: occurrence possibilities}

In fact, what Cienki and Müller (2008) call metaphoric gestures are those that have the potential to engage in an active cross-domain map:

The study of metaphor in gesture is in line with the increasing attention in cognitive linguistics to metaphor as a multimodal phenomenon (e.g., Forceville, 2005; Forceville \& Urios-Parisi, in press). In contrast to a view of metaphor as a disembodied property of written words on a page, research on gesture adds to what we know about how metaphor is expressed and used through multiple modalities at the same time, not only orally/aurally via the words of speech, but also spatio-motorically and visually (CIENKI, 2008, p. 22).

The notion of modality that will lead the discussions to be performed comes from the considerations made by Forceville (2009). The author claims that, although it is difficult to present a thorough compilation of the modes, it is possible to postulate at least nine different modes: "(1) pictorial signs; (2) written signs; (3) spoken signs; (4) gestures; (5) sounds; (6) music; (7) smells; (8) tastes; (9) touch" (FORCEVILLE, 2009, p. 23). As it is possible to observe, the speech - or the "spoken signs" - and the gestures constitute themselves as modes (or "articulatory forms") that are performed in the auditory/oral and visual/spatial modalities, respectively. We therefore intend to discuss how the metaphors can emerge in the auditory/oral and visual/spatial modalities, as well as the possible articulations between these modalities, given that the metaphors carried by these differ between them, as will be demonstrated later in this text.

Generally speaking, in the scope of multimodal metaphors, it is possible to describe three standard occurrences: the first two are quite recurring, whereas the last is extremely rare (MÜLLER \& CIENKI, 2009, p. 307):

a) It is possible to find the same source and the same target in different modalities. Example 2, previously mentioned, shows this occurrence: this is a case of a verbal-gestural metaphor in which the gesture embodies the source domain of the verbal metaphoric expression;

b) It is also possible to find different sources and the same target, in different modalities. In this case there are two possibilities: one 
in which there is a gestural metaphoric expression, with a target verbalized in a non-metaphoric manner, and another in which the gestural metaphoric expression occurs at the same time of the verbal metaphoric expression, although these expressions emerge in distinctive source domains. An example of the first occurrence corresponds to Example 1 (illustrated above): the non-metaphoric target domain is expressed in the speech, whereas the source domain is staged through the gesture;

c) Finally, it is possible - however, quite rare - to find the same source and different targets. Although it is theoretically possible, this occurrence has not been accounted for in any of the analyzed data sets. Cases like these appear to be extremely rare, since the gestures seem to show a tendency to be performed according to the semantics and pragmatics of the verbal utterance. Thus, it can be said that when a source is shared, the target is also shared.

When analyzing the occurrences of the metaphoric expressions through gestures, it is possible to notice aspects related to the gestural metaphoric expressions that are different from the verbal metaphoric expressions. Concerning the source domain, the metaphoric gestures differ from the verbal gestures in aspects such as: duration, position, spontaneity, and, above all, the fact that the gestures constitute themselves as physical forms or movements in space. All of these characteristics reveal particular proprieties of the gestures different from speech - when used as means of expression of the metaphor's source domain. In addition, these characteristics show a relevant property of the gestures, which is that of representing abstract ideas, frequently conveyed in speech, as concrete entities: the gestures indicate specific spaces and places for an idea, or the hands seem to hold an idea as if they were objects.

However, according to Cienki \& Müller (2008, p. 495): "the reification promoted by the gestures should not be seen only as a simple reification of "ABSTRACT AS CONCRETE" (what Lakoff \& Johnson (1980) call ontological metaphors)", since the gestures can also show certain properties of the objects, such as size, spatial location, or even the speaker's evaluation about something, by locating them in a high or low space. In short, the metaphoric gesture study shows that metaphors can occur in different modalities, as well as over time, and even make the complexity of certain situations in which metaphors can occur explicit, such as face-to-face interactions. 


\subsection{Metaphoricity: the metaphor in interactions}

The discussion in the previous section shows the relevance of gestures in the construction of metaphors or metaphoricity in discourse. Thus, a larger notion of language is sustained, in which gestures become relevant elements in the cognitive construction of communicative processes. In addition, the study of gestures in discourse shows that the conceptual metaphor can, in fact, be considered a general cognitive phenomenon, a principle with which we agree because we extensively noticed the occurrence of metaphors in several modalities:

A major conclusion we can draw from the fact that metaphors can be realized in multiple modalities is that metaphoricity is modalityindependent. It documents that the establishment and creation of metaphoricity is a cognitive process with products in various modalities, thus offering strong support for Lakoff and Johnson's (1980) initial idea of moving metaphor(icity) out of the realm of literary discourse into the mundane world of everyday thought (MÜLLER \& CIENKI, 2009, p. 319).

Metaphoric elaborations occur in various modalities and successively in time. When we observe the ways in which the verbal and gestural metaphors are integrated in the ongoing interaction, we observe that the metaphor emergence is gradual and is, consequently, a dynamic propriety, not a static one. Once again, a formulation, such as "TARGET IS SOURCE", reifies the two approached domains in a very narrow and static manner. Therefore, instead of speaking of the conceptual metaphor as a static cognitive principle, metaphoricity is approached as a general cognitive principle, and these metaphorical mappings can be processed online. Therefore, the analysis of the verbal and gestural contexts reveals that metaphoricity is a dynamic property of the linguistic items, which can be found more or less in the foreground and, consequently, receive a more or less focused attention:

The argument is an iconic and an interactive one: the more cues that direct the attention of the interlocutors to the metaphoric quality of a verbal metaphoric expression, the higher the degree of cognitive activation of metaphoricity in the speaker (and also potentially the addressee) (CIENKI \& MÜLLER, 2008, p. 497). 
Therefore, metaphoricity can be analyzed as being a dynamic form of embodied cognition, in other words, the cognitive process of understanding an abstract action as a concrete one, as proposed in the Conceptual Metaphor Theory. Ultimately, the study of metaphors in discourse allows for the analysis of metaphors based on events from a concrete social reality, whereas in the metaphoric emergence, it is based on a shared experience, rather than starting from phrases and situations imagined by the analyst, as was initially done by Lakoff \& Johnson (1980):

We consider descriptions of metaphor not as descriptions of subjective mental experience but as descriptions of shared actions. They gain their intelligibility not from some individual mental processes but from the particulars of concerted, social procedures (CIENKI; MÜLLER, 2008, p. 267)

Thus, the study of metaphoricity is not limited to the analysis of static and permanent characteristics of specific utterances in interaction, as the interlocutors constantly need to explain and reformulate when constructing, whether metaphorically or not, what they said or are saying. Therefore, considering the context as an element in the construction of meaning implies the consideration of the utterances' unfolding in time and space (in other words, the here and now of the enunciation), rather than only considering the context as the development of constantly interactive sequences. Hence, the metaphor is better understood in terms of the social behavior of the participants than in term of the individual mental process.

Thus, from the analyst's point of view, the interaction between the modalities, as well as the interaction between the participants of the enunciative scene, must be taken into consideration, through systematic descriptions of how the construction of meaning is performed at the human level (FAUCONNIER \& TURNER, 2002; AUCHLIN, 2008). However, from the point of view of the multimodal phenomenon analysis methodology, “[a] nalysts' a priori hierarchical division in terms of the relevance of these various senses, and thus of the hierarchical division of resources (first language/talk and then gesture and other conduct that participants employ), is to be avoided" (HOUGAARD \& HOUGAARD, 2008, p. 270). 
The challenge that we intend to face in this research is to perform analyses that take into consideration the time-space unfolding of the face-to-face interactions. We also intend to take into consideration the multimodality inherent to this form of communication, trying to avoid an a priori hierarchization of the modalities when systematically describing the construction of metaphors.

\subsection{Metaphoric gestures and spatial axes in the political discourse}

Based on the considerations of gestures in multimodal metaphors, it is possible to establish the importance of spatial orientation in the emergence and expression of the metaphors. According to Lakoff \& Johnson (1980, p. 18): "Spacialization metaphors are rooted in physical and cultural experience; they are not randomly assigned. A metaphor can serve as a vehicle for understanding a concept only by virtue of its experiential basis." (LAKOFF \& JOHNSON, 1980). These orientational metaphors, which can be summarized by the metaphors "GOOD IS UP" and "BAD IS DOWN", constitute a relevant categorization in the gestural metaphor analysis.

Specifically in political discourse, mainly regarding gestural metaphors, the orientation left-right plays an important role. Calbris (2008), after analyzing six interviews of French Prime Minister Lionel Jospin, showed the importance of the transversal axis analysis, which comprises the symmetry and spatial orientation, to identify and interpret metaphoric gestures. Regarding the symmetry, the author claims that:

Symmetry is knowledge inherent to the body; the right and the left hands function separately (two different autonomous entities); they are physically similar (two equivalent entities, $\mathrm{X}$ or $\mathrm{Y}$ ) and often reunited to act efficiently (two complementary entities, $\mathrm{X}$ and $\mathrm{Y}$ ). Because of this, they have a latent capacity to metaphorically represent two other entities: abstract, different, equivalent, complementary, or even more opposed (CALBRIS, 2008, p. 30). 
See Example 3 below:

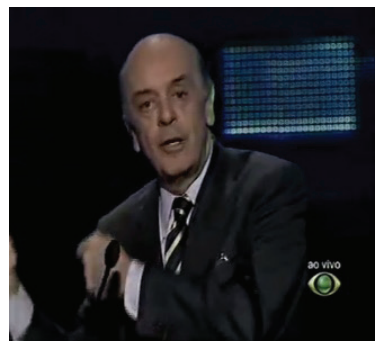

São as tais duas caras que eu disse e repito, uma hora diz uma coisa.

These are those two faces that I said and repeat, one moment she says one thing.

Closed fist, positioned on the left side of the body.

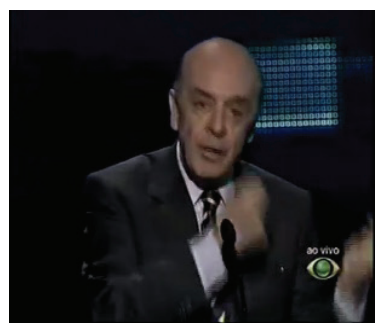

Outra hora diz outra.

The other moment she says something else.

Closed fist on the right side of the body.

Figure 3: Gestures performed on different sides, depicting opposition

Source: Bandeirantes debate

In this example, we have a verbal-gestural representation of metaphors that represent an opposition, expressed at the spatial level: "SAYING ONE THING IS ON THE LEFT" and "SAYING SOMETHING ELSE IS ON THE RIGHT". In addition to the fact that the verbal-gestural representation depicting a contradiction denounced by the candidate, and expressed by the spatial opposition, it also expresses a temporal relation that can be formulated as follows: "THE FUTURE IS AHEAD" - in this case, to the right - and "THE PAST IS BEHIND" - in this case, to the left. Thus, corporal symmetry expresses not only the spatial relation, but also the temporal relation:

A path in space or time is depicted by a left-to-right movement. But given that body symmetry allows this axis to account for splitting in two as well as two-entity oppositions, it can be used to oppose past and future, or precedence and succession, by locating the past on the left side and the future on the right side (CALBRIS, 2008, p. 42).

In addition to the left-right opposition, it is possible to explore the horizontal and vertical axes, as can be seen in Example 4 below: 


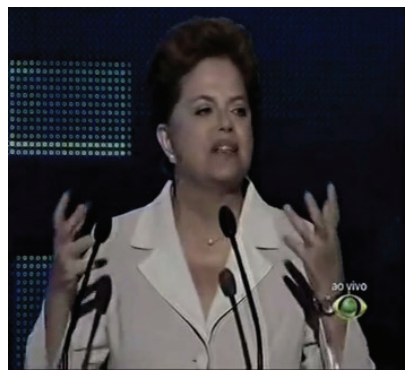

Eu acho que uma candidatura à presidência, ela tem por objetivo engrandecer o Brasil.

I think that a presidential candidacy is aimed at enhancing Brazil.

Arms rising vertically and hands with palms directed upwards.

Figure 4: Rising gestures performed with both hands, representing growth Source: Bandeirantes debate

In this example, the gesture performed with both hands, from the middle and up, represents growth: "Physical growth is manifested by an increase in height, and no matter which kingdom (animal or vegetable) it belongs to, the mature adult is stronger, in two senses of 'strong"' (CALBRIS, 2008, p. 47). Calbris' theoretical formulation can be summarized according to the image below:

Table 1: Left-right axes opposition

\begin{tabular}{|c|c|c|c|}
\hline \multirow{4}{*}{ (A)Symmetry } & LEFT & & RIGHT \\
\hline & clumsy & & skilful \\
\hline & others & -1 & oneself \\
\hline & accessory & & important \\
\hline 1. Growth & negative, inferior & ------•-----.> & superior, positive \\
\hline 2. Walking & last, second & $-\cdot-\cdot-\cdot 0---\cdot-\rangle>$ & first (arrived) \\
\hline 3. Writing & old & $-\cdots-\cdot \cdot-\cdot---\rangle>$ & new \\
\hline & NEGATIVE VALUES & & POSITIVE VALUES \\
\hline
\end{tabular}

Source: CALBRIS, 2008, p. 50

In another study, Casassanto and Jasmin (2010) analyzed a large set of gestures from the final debates of the 2004 and 2008 American Presidential Elections. They concluded that the candidates associated positive messages to the hand they use most and negative messages to the hand they least use. That is, the right-handed used the right hand to pass on positive messages and the left hand to pass on negative messages, whereas the left-handed did the opposite. In this case, it would not be possible to create a standard, such 
as "GOOD IS ON THE RIGHT" and "BAD IS ON THE LEFT", as the use of hands would be directly related to the decreased or increased use of a specific hand within the interaction with the environment. These data contradict the analyses performed by Calbris (2008), which supports the hypothesis that, as most part of the population is right-handed, society ends up adopting the majority's point of view and, subsequently, "the asymmetry to the advantage of the right becomes cultural" (CALBRIS, 2008, p. 46).

This hypothesis is empirically supported by the analyses performed by Cienki (2008). In the metaphorical gestures, representing opposite abstract entities, a spatial division resource is used: the opposite sides of the body are used to demonstrate an opposition expressed in the speech. In this work, we will adopt the hypothesis raised by Calbris (2008) and empirically supported by Cienki and Müller (2009), as we extensively found data that prove this hypothesis, both in the case of Serra, the right-handed candidate, and in Dilma, the left-handed candidate, as will be demonstrated in the example analyzed below.

\section{Metodology}

\subsection{Analysis corpus}

To analyze the spatial orientation metaphors within the political discourse, we have selected four excerpts of the second-round political debate, broadcasted by TV channel Record. The main subjects of the debate, for each of the candidates, were the following:

Table 2: Main subjects for each candidate in the second turn debates

\begin{tabular}{|l|l|}
\hline \multicolumn{2}{|l|}{ Record Debate } \\
\hline Dilma & $\begin{array}{l}\text { Privatization of state-owned enterprises, Social programs of } \\
\text { the Lula government, Environment }\end{array}$ \\
\hline Serra & Corruption, health, public security \\
\hline
\end{tabular}

Source: Adapted from Wikipedia 
It is important to highlight that, in the elections' second round, there were several controversial issues. These issues, specially raised during the debates, were useful to increasingly show the ideological differences between PT and PSDB, at least in the discourse: Dilma favored the continuation of social programs, revealing a left-wing position, linked to the welfare state, as opposed to the privatization of state-owned enterprises, and concerned about employment policies and the environment. Serra, on the other hand, reveals a right-wing position, focusing on traditionally more conservative subjects, such as public security, corruption, and abortion. However, this right-wing position is not explicitly assumed, given the fact that the president at that time, Lula, and consequently his party's political welfare platform, had an unprecedented popularity of $82 \%$.

Serra could not explicitly defend Minimal State ideas, defended by his party (PSDB), as this would go against public opinion. When confronted with his ideological affiliation to a right-wing agenda, the candidate avoided the issue, claiming that he thinks with his own head and plans to continue Lula's social programs. He frequently replied with examples of the PT corruption scandals, widely rebuffed by the public opinion and extensively diffused by the press, mainly by Veja Magazine, during Lula's entire term of office.

Prototypically, the excerpts selected for analysis consist of questions, answers, replies, and responses. We have selected four successive excerpts: one in which Serra formulates an answer regarding health in Brazil, followed by another excerpt in which Serra asks about Petrobras and oil, followed by an excerpt in which Dilma asks a question regarding employment, and, finally, an excerpt in which Serra asks a question about security. However, despite the thematic diversity of the questions, answers, replies and responses from both candidates focused mainly on Petrobras and the oil question in Brazil. In addition, as we claimed above, several controversial questions were raised: both candidates tried to disqualify their opponent, both through comparisons between the two political parties to which the candidates belong, as well as by questioning the moral conduct of the opponent. In these controversial moments, spatial orientation metaphors were used, as we will show in the data analysis.

\subsection{Gesture categorization}

From the operational point of view, in order to analyze the gestures, it is necessary to define the parameters to identify the body action units 
that could be considered gestures. Based on the categorization proposed by Kendon (2004), the gestures were considered to be "(...) identifiably distinct effortful movements of the hands and forearms, that is, gesture strokes" (CIENKI, 2005, p. 425), including three phases in which a movement excursion is performed - also called a Gestural Unit - or an "excursion succession" (KENDON, 2004, p. 110):

a) Preparation: optional phase, in which the limbs move from a relaxed or resting position;

b) Stroke: mandatory phase, in which the gestural expression is performed, showing clear dynamic movements that require the focus of both effort and energy. In this phase, considered the gesture's peak, hands tend to describe forms and complete movement patterns, or a brief stop in the movement, in which the limbs are kept still before relaxing and returning to the initial position. This second possibility was called post-stroke hold (KITA apud KENDON, 2004, p. 112). The combination of stroke and post-stroke can be considered a "gestural phrase" (KENDON, 2004), as these are phrases that convey meaning or the gestural expression;

c) Retraction: optional phase, in which there is a movement retraction toward the initial relaxed or resting position.

To perform a pragmatic analysis of the gestures, it is necessary to approach two concepts: Gestural Unit (GU) and Gestural Phrase (GP). The GU can be defined as the complete excursion of the movements, which starts (preparation) and ends (retraction) with the relaxing of the limbs and reaches its peak in the stroke. The GU can include one or more GP's: these are identified in every performed stroke or gestural stroke action sequence. The stroke is performed when the limbs are moved into a specific direction. In other words, the movement patterns of the body parts involved in the gesticulation are more explicitly defined. This specific movement only occurs after the limb positioning, which corresponds to the preparation phase. Thus, the GP encompasses the preparation phase and the stroke phase, as well as eventual hold phases (pre and post-stroke) between the stroke and the retraction. Like linguistic phrases, gestural phrases also show a structure analog to the syntactic structure, closely linked to the co-occurrence of gestures together with speech: 
The nucleus of the gesture phrase, that is, the stroke and the held phase that may follow it, tends to be performed in such a way that it is done at the same time, or nearly at the same time as the word or the word cluster that constitutes the nucleus, in a semantic sense, of the spoken phrase. This means that, by coordinating temporally the nucleus of the gesture phrase (i.e. the stroke and any post-stroke hold) with the semantic nucleus of the spoken expression, the speaker achieves the conjunction of two modes of different expressions which, as we have said, also have semantic coherence one with the other (KENDON, 2004, p. 125).

It is important to highlight that, although there is a co-occurrence relation between gestures and speech, these are seen as distinct means of expression: the gestures, as visual utterances, and the sentences, as verbal utterances, which, in face-to-face interactions, are related to the auditory modality. The coherence between gestures and speech - called co-expressivity by McNeill (2005) - is a clue that the gestures and speech are part of a single system, as hypothesized by McNeill (2005) and Hostetter \& Alibali (2008). In this way, when creating a single utterance using two different means of expression, "(...) the speaker creates an ensemble in which gestures and speech are employed together as partners in a single rhetorical enterprise (KENDON, 2004, p. 127).

\subsection{Data analysis}

When analyzing the selected excerpts, we found eleven occurrences of spatial orientation metaphors: three of these are predominantly verbal occurrences, that is, the forearms and hands remain in a resting position during the transmission of the utterance, whereas the remaining occurrences are predominantly verbal-gestural.

\subsubsection{Predominantly verbal metaphors}

In the first sample presented, Serra asks a question about health. Before asking the question, the candidate discourses on health in Brazil.

\section{Sample \# 1}

Serra: Bem, uma outra questão que eu gostaria de perguntar é a respeito da saúde no Brasil. A saúde no Brasil andou pra trás. Basta olhar em todas as pesquisas que a gente vê nesse sentido. 
Well, another question that I would like to ask concerns health in Brazil. Health in Brazil has fallen back. We only need to look at the surveys to see that way.

Both metaphors presented are very conventional ones, related to spatial orientation. The first, "REGRESSING IS GOING BACKWARDS", is part of the more general set "GOOD IS GOING FORWARD" and "BAD IS GOING BACKWARDS". In turn, the second metaphor used, "SEEING SOMETHING IS SEEING IN A DETERMINED WAY", is part of the set "KNOWING IS SEEING". In this context, the metaphors work as criticism to the situation, represented by candidate Dilma, regarding health.

In the second sample, Serra asks a question about security:

Sample \#2

Serra: Minha pergunta agora é sobre segurança. Segurança no Brasil é um problema grave. Aliás, segurança, ao lado da saúde e educação, é um dos problemas que mais afligem a nossa população. E segurança tem andado pra trás nos últimos anos.

My question now is about security. Security in Brazil is a serious problem. Besides, security, together with health and education, is one of the problems that most afflicts our population. And security has been falling back in the past few years.

To show that the importance given to health and security is the same, the candidate uses a metaphor in which the subjects are at the same spatial level: next to each other. In the following excerpt, the metaphor "REGRESSING IS GOING BACKWARDS" is used, which results in criticizing the current security situation in the country.

In the next sample, Serra is initiating his reply to the health question:

Sample \#3

Serra: É, como todos viram, ela não respondeu à pergunta sobre a saúde, né, é uma coisa tão importante pro Brasil hoje. E ela não indicou os caminhos. 
Well, as everybody saw, she did not answer the question on health, right, it's something so important for Brazil today. And she did not show the way to move forward.

Once again, the candidate uses a metaphor belonging to the set "KNOWING IS SEEING", whose variant, in this context, would be "Proving IS SEEING". The candidate establishes a close relation with the interlocutor, although he does not specify it, calling him/her in as a witness to the fact that the candidate did not answer his question. The provocative perlocutional effect is strengthened by using the metaphor "MAKING PROPOSALS IS SHOWING THE WAY". Both metaphors used here are of a conventional nature.

\subsubsection{Predominantly verbal-gestural metaphors}

In the first two gesture samples (Sample \#4 and Sample \#5), both candidates denounce contradictions in their opponent's behavior. In the first sample, shown below, Dilma, in her response, questions Serra's contradictory behavior regarding the University for All Program (PROUNI):

\section{Sample \#4}

Dilma: O candidato José Serra não respondeu se vai pedir pro vice dele retirar a ação de inconstitucionalidade contra o PROUNI. Então, a gente fica em dúvida também a respeito de qual é a sensibilidade dele, que diz que vai fazer o PROUNI (1) mas num retira a ação (2).

Candidate José Serra did not answer if he is going to ask his vice to withdraw the unconstitutionality lawsuit against PROUNI. So, we also remain in doubt regarding his sensibilities, he says that he is going to do PROUNI (1) but doesn't withdraw the lawsuit (2).

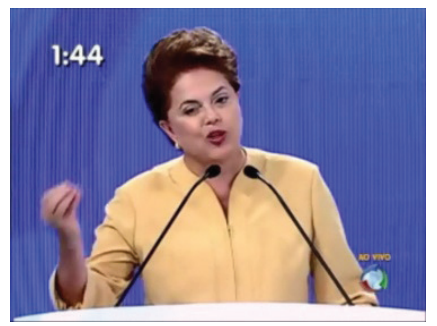

Right hand on Dilma's right side, with finger points closed and touching. 
(2)

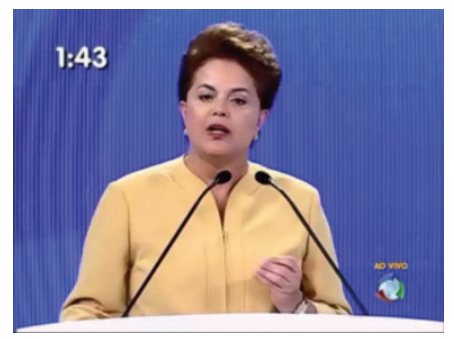

Body leaning to the left side, with his right arm moving to the left and his right hand closing together with the left hand.

The doubt, which is clear in the first utterance, is strengthened by using opposite gestures, which embody the contradiction expressed in the speech, expressing the following metaphor: "CONTRADICT ONESELF IS TO ASSUME OPPOSITE POSITIONS IN SPACE”. Dilma uses precision gestures ( $G$-family gestures, see also Kendon, 2004), which are performed when she describes the contradictory actions of her opponent.

In the following sample, at the end of the question about Petrobras, Serra points out a contradiction in Dilmás behavior regarding the company's privatization.

\section{Sample \#5}

Serra: Ela entregou, a Petrobrás entregou, é, exploração de petróleo para cento e oito empresas privadas, metade mais ou menos estrangeiras, metade mais ou menos nacionais. Logo, há uma contradição, não é coerente a acusação que ela me faz (1) com o que ela fez (2) na prática de governo.

She handed over, Petrobras handed over, oil exploration to a hundred and eight private companies, half, more or less, foreign, half, more or less, national. So, there is a contradiction, it isn't coherent the accusation that she makes against me (1) with what she did (2) in her government's practice.

(1)

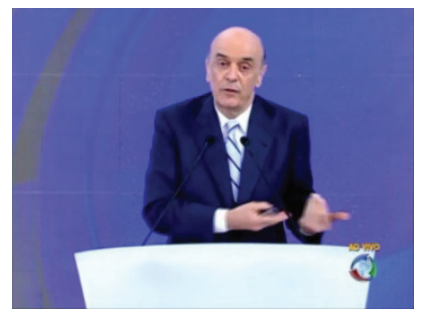

Body leaning to the right side, with his right hand moving to the right and his right hand opening and pointing to the opponent. 
(2)

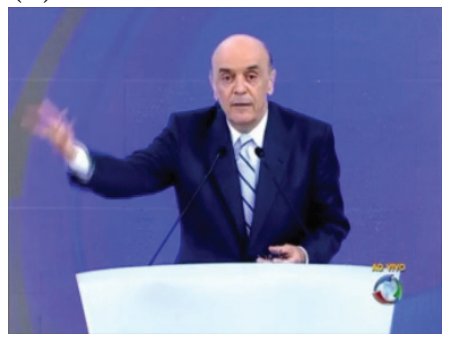

Body leaning to the right side, with his right hand moving to the right and his right hand opening and pointing to the opponent.

Once again, we can notice the use of the metaphor "CONTRADICT ONESELF IS TO ASSUME OPPOSITE POSITIONS IN SPACE". The contradiction expressed in the speech is highlighted through gestures: both body, which takes opposite positions in space, and the right arm and hand, which make opposite movements - close first and open afterwards.

In the two following samples (Sample \#6 and \#7), Serra, in his response, points out contradictions between Dilma's behavior and discourse, both in what she says regarding privatization and regarding abortion, which were controversial subjects that were widely debated during the second round of the elections. ]

Sample \#6.

Serra: Ou seja, o que ele fez teria sido privatização, deu para as empresas privadas, estrangeiras e nacionais. No entanto quando é no caso do pré-sal, quem quer fazer isso é privatizante e é o capeta, é um demônio.

In other words, what she did would be privatization; she gave it to private companies, foreign and national. However, when it is about pré-sal, who wants to do this is privatizing and is the devil, a demon.

(1)

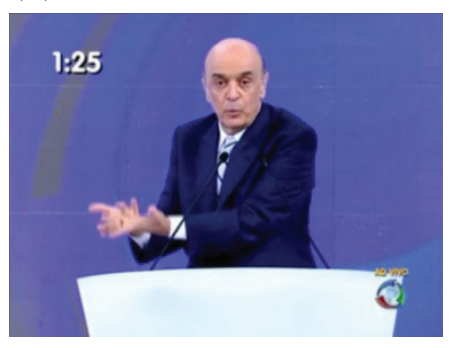

Hand and forearms moving from left to right. 
(2)

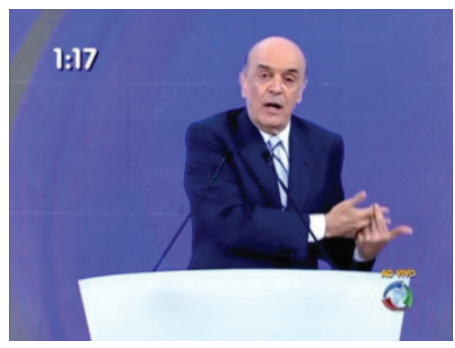

Sample \#7

Serra: Ela diz sou contra o aborto (1), sou a favor do aborto (2), sou contra privatizar telecomunicações (1), sou a favor de privatizar telecomunicações (2), sou contra privatizar exploração do petróleo (1), eu fiz privatização da exploração do petróleo (2).

She says: I am against abortion (1), I am in favor of abortion (2), I am against privatizing telecommunications (1), I am in favor of privatizing telecommunications (2), I am against privatizing oil exploration (1), I privatized oil exploration (2).

(1)

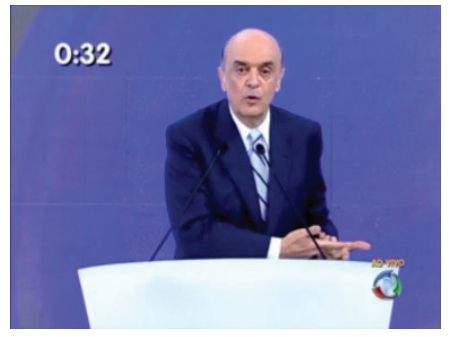

Hand and forearms moving from left to right, repeatedly.

(2)

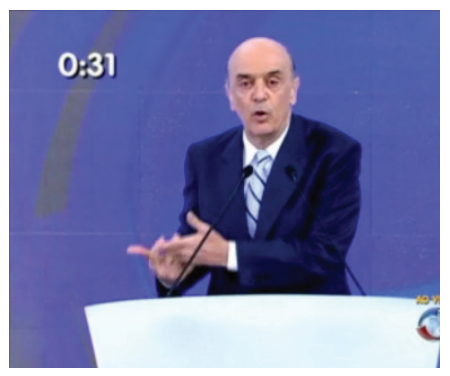


In these two samples, the act of denouncing contradictory positions, expressed by the hands that go from one side to another, can be noticed. Here, 'being against' means that the left side is occupied, and 'being in favor' means that the right side is occupied, which corroborates with Calbris' hypothesis (2008) that negative values are positioned on the left and positive values on the right. Once again, the candidate uses the metaphor "CONTRADICT ONESELF IS TO ASSUME OPPOSITE POSITIONS IN SPACE". In addition, the movement also shows a temporal dimension, in which, at some point in time, one thing is said, and afterwards the opposite is said.

In the next four samples - Samples \#8 to \#11 - the examples can be considered as illustrations of the metaphors: "THE FUTURE/GOOD IS ON THE RIGHT" $\mathrm{x}$ “THE PAST/BAD IS ON THE LEFT". As indicated by Calbris (2009), the past is located on the left and the future on the right, reproducing the evolution axis adopted by Western societies, from left to right.

In Sample \#8, Dilma, in the beginning of her answer about Petrobras, says:

Sample \#8

Dilma: Candidato Serra, o pré-sal é um bilhete premiado (1). E nós podemos dividir a história do pré-sal em dois momentos: antes do pré sal (2) e depois do pré sal (3).

Candidate Serra, the pré-sal is a winning ticket (1). And we can split the pré-sal history into two moments: before pré-sal (2) and after pré-sal (3).

(2)

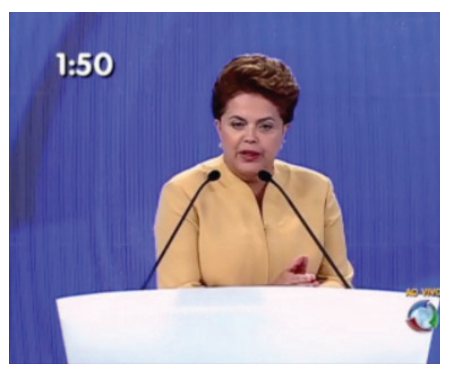

Joint hand palms positioned on the left side of the body, with extended fingers. 
(3)

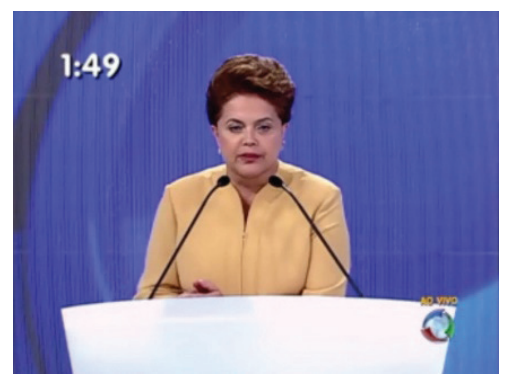

Joint hand palms, with extended fingers and on the right side of the body.

In this sample, Dilma starts her speech conveying an intentional verbal metaphor (1) that will be repeated several times during the debate: "OTHER OIL RESERVES ARE WINNING TICKETS". The metaphor would be part of the set "IDEAS ARE OBJECTS". In the second part of the sequence $(2,3)$, Dilma tries to establish a distinction between past and future. The division expressed in the speech is also expressed by the gestures: before is on the left and after is on the right.

In the following sample - Sample \#9-Dilma, in a question, exploits the opposition between Fernando Henrique Cardoso's and Lula's governments regarding job creation.

Sample \# 9

Dilma: Olha, eu vou fazer uma pergunta que eu tenho feito sistematicamente e que diz respeito ao emprego, que é a seguinte: o nosso governo (1) criou quase quinze milhões (2) de empregos formais. $\mathrm{O}$ do Fernando Henrique (2) criou cinco milhões. Então, eu pergunto pro candidato: o que você pretende fazer, candidato, pra não repetir o desastre (4) da administração anterior em matéria de geração de emprego.

Look, I'm going to ask a question that I have systematically asked, regarding employment, which is the following: our government (1) created almost fifteen million (2) formal jobs. Fernando Henrique's (3) created five million. So, I ask you: what do you pretend to do, sir, to avoid repeating the disaster (4) of the previous administration regarding job creation. 
(1)

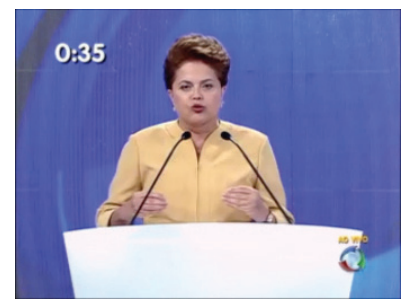

(2)

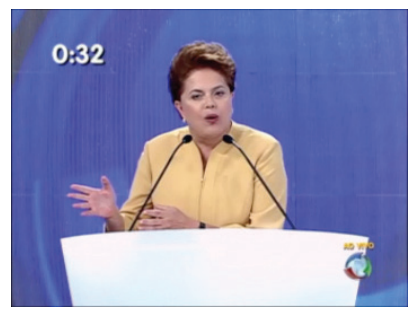

(3)

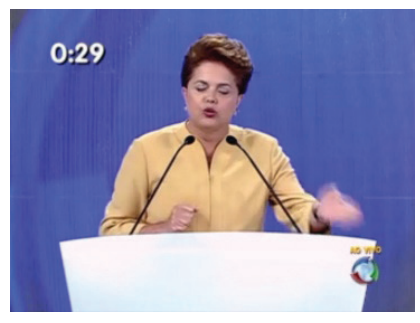

(4)

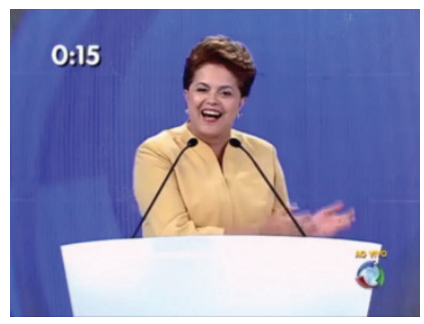

Descending gesture with both hands, positioned at the center.

Descending gesture with both hands, positioned on the right side of the body.

Descending gesture with the left hand, fingers extended.

Forearms positioned on the left side, descending gesture, with hand palms turned upwards.

In this sample, together with the first gesture, the use of the pronoun "our" is a relevant language feature used by Dilma. It is used to show that she belongs to Lula's government, that enjoyed a record popularity, and to make the classic distinction: "We", the good doers x "They", the wrongdoers (VAN DIJK, 2008). After that, a spatial division establishing the difference between 
before/bad $\mathrm{x}$ after/good is promoted by the second and the third gestures. Finally, the metaphor "MiSMANAGEMENT IS A DISASTER" is used, in which the critics, through references to tragedies, are complemented by the gestural metaphor "BAD IS DOWN", which establishes a relation of complementarity with the speech by using an orientational metaphor.

Samples \#10 and \#11 are part of Dilma's reply to the employment subject, which turned into a discussion about the pré-sal and Petrobras. Next, we will present the full sequence of the speech and, afterwards, it will be unfolded through the referred samples.

Dilma: Privatizar o pré-sal, candidato, é um absurdo e é isso que vocês propóem sim. O seu partido votou contra o modelo de partilha. $\mathrm{O}$ senhor não tem coragem de assumir a sua posição (1), e que fica falando que num se influencia (2) pelos outros (2). Ora, então, o senhor tá no partido errado. O seu partido vota contra a garantia que a Petrobrás será a exploradora do pré-sal. Aliás essa fala (3) dele de "a maioria dos blocos serem estrangeiras", ela é mentira (...). Porque, na maioria dos casos, há o controle da Petrobrás pelos blocos. A questão não é essa (4). A questão é que no modelo anterior (5) tudo ficava para a empresa, a empresa estrangeira ou para qualquer empresa. Agora não (6): agora, como é muito dinheiro e o recurso é muito grande, e é bom que você saiba que a grande maioria dos países agiu dessa forma: descobriu reservas do tamanho do pré-sal.

Privatizing pré-sal, candidate, is absurd and this is what you propose. Your party voted against the shared model. You don't have the courage to assume your position (1), and you keep saying that you're not influenced (2) by the others (2). Well, then you are in the wrong party. Your party votes against the guarantee that Petrobras will be the pré-sal's operating company. What is more, what he says (3), that "the majority of the blocks are foreign", is a lie (...). Because, in most cases, there is a Petrobras control over the blocks. The question isn't that (4). The question is that in the previous model (5) everything remained in the hands of the foreign company or any other company. Not now (6): now, as it is a lot of money and the resources are huge, and it is good for you to know that the vast majority of the countries acted this way: they discovered pré-sal-sized reserves. 
As was previously mentioned, the reply will be unfolded into two gesture samples. In Sample \#10, Dilma uses the perlocutionary effect of irony.

Sample \#10

Dilma: $\mathrm{O}$ senhor não tem coragem de assumir a sua posição (1), e que fica falando que num se influencia (2) pelo os outros (3). [...] Aliás, essa fala (4) dele de "a maioria dos blocos serem estrangeiros", ela é mentira.

You, sir, don't have the courage to assume your position (1), and you keep saying that you're not influenced (2) by the others (3). [...] Besides, what he says (3), that "the majority of the blocks are foreign", is a lie.

(1)

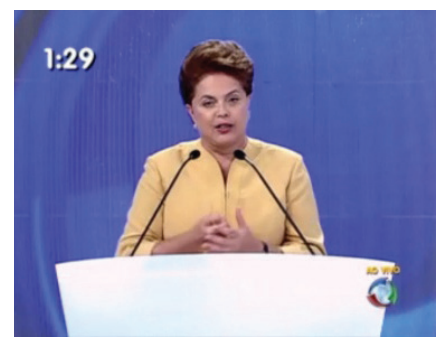

(2)

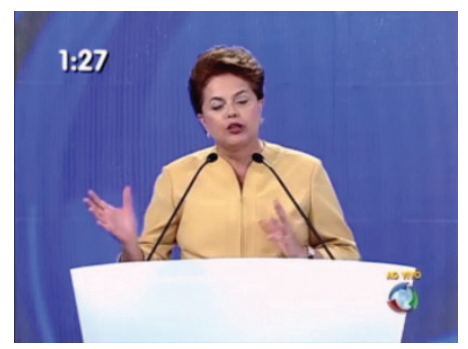

(3)

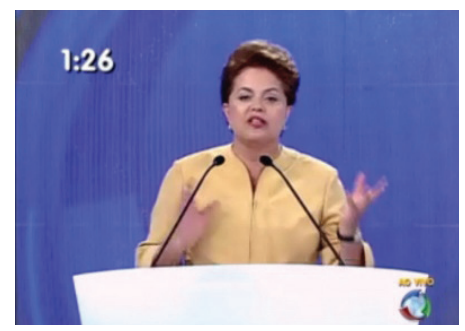

RBLA, Belo Horizonte, v. 15, n. 2, p. 343-376, 2015
Right hand punching the left hand.

Hands falling from one side to another, repeatedly. 
$(4)$

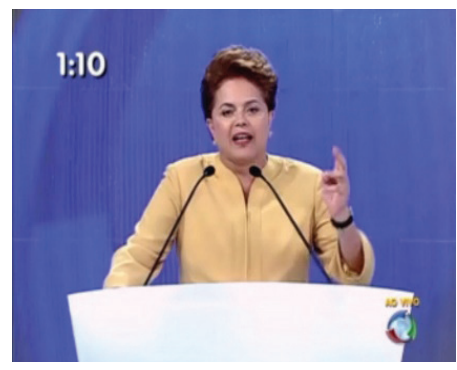

Left hand vertical, with the index and middle fingers that stretch and bend.

In gesture sequences 1 to 3 , the metaphor "COWARDICE IS FALLING FROM ONE SIDE TO ANOTHER" is staged by gestures and bolstered by the reported speech. Therefore, the gestures embody Dilma's discontent regarding Serra's attitudes, whereas the verbal content expresses discontent regarding the opponent's discourse. The combination of speech and gestures reveals an ironic way of pointing out the opponent's flaws. Yet, gesture 4 stages the quotation marks, resource used to discredit Serra's speech, which will be characterized as "a lie", directly after. The gesture can be considered ironic. It is relevant to notice that the irony mainly comes from the gesture.

In Sample \#11, Dilma explores the opposition "past x future".

Sample \#11:

Dilma: A questão não é essa (5). A questão é que no modelo anterior (6) tudo ficava para a empresa a empresa estrangeira ou para qualquer empresa. Agora não (7): agora, como é muito dinheiro e o recurso é muito grande (...)

The issue is not that one (5). The issue is that in the previous model (6) everything remained in the hands of the foreign company or any other company. Not now (7): Now, as it is a lot of money and the resources huge (...) 
(5)

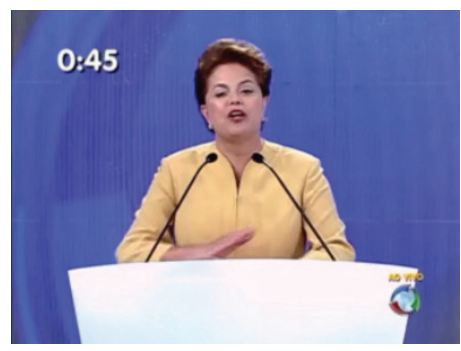

Zip-gesture: right hand is crossed below the left hand, and afterwards, both hands are opened horizontally.

(6)

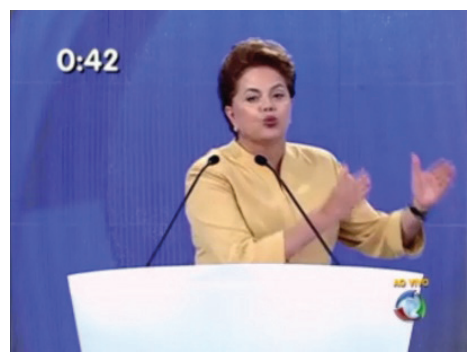

Hands positioned on the left side of the body, palms turned facing each other.

(7)

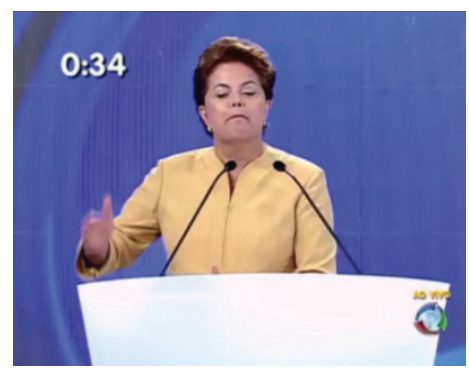

Right hand positioned on the left side of the body, descending movement.

In this sample Dilma, firstly, uses a pragmatic cutting gesture (ZPgesture, see also Kendon, 2004) to indicate the interruption of an idea, which can also be noticed in the speech. Afterwards, she compares the measures taken by Fernando Henrique Cardoso's government, using the left side, to measures adopted by Lula's government, positioning the right hand on the right side. Once again, the hypothesis that the past and the negative values are located on the left side, whereas the future and the positive values are located on the right side, is proven. 


\section{Results and discussion}

After analyzing the metaphors found in the four debate sequences, we deemed it convenient to resume the metaphoricity question in an attempt to establish a continuum between metaphors of a conventional nature and those of a new nature. In the scheme below, a continuum linked to spatial orientation metaphors is illustrated:

\begin{tabular}{lll}
\hline+ conventional & & + new \\
Visual metaphors $\quad$ Spatial Metaphors on walking/ways & Metaphors on position
\end{tabular}

Regarding the entrenchment degree of the metaphors in the conceptual system, we started from the assumption that visual metaphors, such as "as all saw it, she did not answer the question on health", are used in an almost automatic way by the speaker. These expressions are so entrenched in our conceptual system that it becomes almost difficult to identify them as metaphors. On the other hand, the metaphors about position, especially those staged by gestures and in an ironic way, have a newer status. However, we believe that the great novelty, in these cases, is fairly linked to the ironic use of language - and not necessarily to the metaphoric use. Actually, the orientational metaphors found in our corpus are generally of a fairly conventional nature.

Regarding the inter-relation between gestures and metaphors, we based ourselves on the Conceptual Metaphor Theory, in which "each conceptual metaphor consists of the systematic mapping of entities and relations from a sensorimotor source domain to a target domain that is abstract" (JOHNSON, 2007, p. 165), and we present, in our analyses, a broader discussion on the relation between metaphors and gestures in political-electoral debates. The connection or integration between spoken language and gestures showed that metaphors can be instantiated in several modalities, without necessarily conveying the same conceptual metaphor, as proposed by Cienki and Müller (2008). Taking the relation between gestures and speech into account, it was possible to build a gesture scale, from the analyses we performed.

Gestures staging speech $>$ Gestures strengthening speech (pragmatic gestures) $>$ Gestures complementing speech $>$ Gestures being completed by speech (gestures: source domain and speech: target domain). 
From our analyses, it was possible to prove that the gestural data not only replicate the conceptual metaphors given by the verbal data, but they also provide additional clues to multimodal mappings that can, inclusively, be the source of the gestures (CIENKI, 2008). The analysis of the verbal variables, as well as the gestural variables and, above all, the link between these variables, allows one to overcome the circularity criticism made by the Conceptual Metaphor Theory, addressed in the first section of our paper (CIENKI, 2008).

\section{Conclusion}

When specifically addressing the strategies used by Candidates Dilma and Serra during the political-electoral debates analyzed in this study, it is possible to analyze the multimodal metaphors used by each candidate. From the performed analyses, we noticed that Dilma makes more gestures when using metaphors, often using the resource of comparing both governments, Lula's and Fernando Henrique Cardoso's, through the spatial opposition metaphor. In addition, she frequently associates the verbal metaphors with pragmatic precision or interruption gestures, which strengthen or complete the metaphoric meaning of the phrases. In addition, she uses gestures to convey a perlocutionary effect of irony, configuring a quite diverse use of gestural resources. Finally, Dilma makes a great use of metaphors and gestures in her speech, which would further direct the audience's attention both to what is being said as well as to how it is being said.

Regarding the metaphors used by Serra, we notice that he often uses conventional metaphors, sometimes unaccompanied by gestures. The use of gestures often occurs when denouncing the contradictory behaviors of his opponent. It is relevant to note that, as Lula's government and the projects developed at the time show a very high approval rate, Serra does not openly criticize them, while concomitantly trying to detach himself from his party's image. How can the differences in the uses of metaphors in the national political context be interpreted? How can they be associated to the election results? It is important to bear the premise raised by Lakoff (2004) in mind, that the elector's identification with certain values is crucial for a good outcome in the elections.

According to Lakoff (2004, p. 5), from the political point of view, the conveyed values come from family values. Therefore, they come from the more ordinary metaphor "THE NATION IS A FAMILY". Taking into account 
that there are basically two distinct ways of seeing the nation (related to the left and right-wing concepts), they should be linked to two distinct ways of seeing family models: one model based on the father figure, which would be based on the strict-father policy moral system, related to the right-wing values, and another model based on the mother figure, which would be based on the protective mother figure, related to the left-wing values. The moral values that direct each of those systems can be summarized as follows:

Table 2: Left-wing moral values $\mathrm{x}$ right-wing moral values

\begin{tabular}{|l|l|}
\hline Progressive & Conservative \\
\hline Stronger country & Stronger defense \\
\hline Broad prosperity & Free markets \\
\hline Better future & Lower taxes \\
\hline Effective government & Smaller government \\
\hline Mutual responsibility & Family values \\
\hline
\end{tabular}

Source: LAKOFF, 2004, p. 94

It is essential to understand that conveying values corresponds to conveying ideas: "the right use of language starts with ideas (...) When you think you just lack words, what you really lack are ideas. When the frames are there, the words come readily" (LAKOFF, 2004, p. 23). Therefore, it is possible to say that Dilma, when talking about the social programs of Lula's government and promoting comparisons between Lula's and Fernando Henrique Cardoso's government, is building a clear framing of "We, protectors of the nation" $\mathrm{x}$ "They, the predators of the nation". This demagogy effect mobilizes the passion of the voters, such as the fear of the opponent and the trust in the candidate. In other words, in the case of Dilma, the constructed frame corresponded to the values to which the voters identified themselves, as well as their interests.

Serra, on the other hand, when using gestures to separate opposite ideas, builds a frame in which MORAL CONTRADICTION corresponds to Spatial OPPOSITION. However, when performing a framing of the opponent as contradictory and morally doubtful, Serra disqualifies her, but does not build a clear framing of himself. He also takes advantage of demagogy, when placing himself as the protector of family values and religion, but he does this by accusing the opponent, assuming contradictory positions regarding belief in God, corruption, and support of abortion. 
The fact that he is trying to distance himself from his party's proposals and to position himself as the continuator of Lula's government social programs, although he is from the opposition, results in a lack of clarity regarding the frame built by him. At the same time that he invokes the frame of a strict-father policy, he also invokes the protective mother frame and protector of the national interests, although he belongs to a political party that is, historically, known for defending opposite policies. However, the values framed by the candidate are ambiguous, which can result in distrust on the part of voter and in a failure of the persuasion strategies used.

In conclusion, the analysis of the multimodal metaphors used by the candidates allowed us to unravel the strategies they used to relate themselves to certain value systems and thereby conquer or not the elector's vote. The performed analyses allowed us to corroborate the hypothesis that our conceptual system is much larger than our linguistic system. For this reason, language is expressed through various modalities, and in a political campaign, words are not sufficient to build strategies. The activation of framings belonging to our conceptual system constituted a decisive mechanism for building the candidates' images and, above all, to capture the electors' votes.

\section{References}

CALBRIS, G. From left to right...: coverbal gestures and their symbolic use of space. In: CIENKI, A.; MÜLLER, C. (Eds.). Metaphor and gesture. Amsterdam: John Benjamins, 2008. p. 27-54.

CASSASSANTO, D; JASMIN, K. Good and bad in the hands of politicians: spontaneous gestures during positive and negative speech. Plos one. v.5, n.7, p.1-5, 2010. Available at: <http://www.plosone.org/article/ info\%3Adoi\%2F10.1371\%2Fjournal.pone.0011805> Accessed May 21, 2014.

CIENKI, A. Why to study metaphor and gesture? In: CIENKI, A.; MÜLLER, C. (Eds.). Metaphor and gesture. Amsterdam: John Benjamins, 2008. p. 3-26.

CIENKI, A.; MÜLLER, C.. Metaphor, Gesture, and Thought. In: GIBBS, R. (Ed.). The Cambridge Handbook of Metaphor and Thought. Cambridge: Cambridge University Press, 2008. p. 483-501.

FAUCONNIER, G.; TURNER, M. The Way We Think: Conceptual blending and the mind's hidden complexities. New York: Basic Books, 2002.

FORCEVILLE, C.. Non-verbal and multimodal metaphor in a cognitivist framework: Agendas for research. In: FORCEVILLE, C.; URIOS-APARISI., E. (Eds.). Multimodal Metaphors. Berlin and New York: Mouton de Gruyter, 2009. p. 4-19. 
GIBBS, Raymond. Metaphor Interpretation as Embodied Simulation. Mind \& Language, v.21, n.3, p. 434-458, 2006.

HOSTETTER, A.; ALIBALI, M. Visible embodiment: Gestures as simulated action. Psychonomic Bulletin \& Review, v. 15, n. 3, p. 495-514, 2008.

HOUGAARD, A.; HOUGAARD, G. Implications of cognitive metaphor and gesture studies for Ethnomethodology and Conversation Analysis and vice versa. In: CIENKI, A.; MÜLLER, C. (Eds.). Metaphor and gesture. Amsterdam: John Benjamins, 2008. p. 265-273.

LAKOFF, G. Don't think of an elephant! Know your values and frame the debate: the essential guide for prograssives. Chelsea: Chelsa Green Publishing, 2004.

LAKOFF, G.; JOHNSON, M. Metaphors we live by. Chicago and London: The University of Chicago Press, 2003 [1980].

MÜLLER, C.; CIENKI, A.. Words, gestures, and beyond: Forms of multimodal metaphor in the use of spoken language In: FORCEVILLE, C.; URIOSAPARISI, E. (Eds.). Multimodal Metaphors. Berlin and New York: Mouton de Gruyter, 2009. p. 297-328.

SONESSON, G. De l'iconicité des images à l'iconicité des gestes. In: CAVE, C. ; GUÏTELLE, I.; SANTI, S. (Eds.). Oralité est gestualité: Interactions et comportements multimodaux dans la communication. Actes du colloque ORAGE 2001, Aix-enProvence, 18-22 juin 2001. Paris: L'Harmattan, 2001. p. 47-55.

Data de submissão: 01/08/2014. Data de aprovação: 06/01/2015. 